\title{
Androgen responsiveness to competition in humans: the role of cognitive variables
}

\author{
This article was published in the following Dove Press journal: \\ Neuroscience and Neuroeconomics \\ II February 2014 \\ Number of times this article has been viewed
}

\author{
Gonçalo A Oliveira' \\ Rui F Oliveira ${ }^{1,2}$ \\ 'Unidade de Investigação em \\ Eco-Etologia, ISPA - Instituto \\ Universitário, Lisbon, Portugal; \\ ${ }^{2}$ Champalimaud Neuroscience \\ Program, Instituto Gulbenkian de \\ Ciência, Oeiras, Portugal
}

\begin{abstract}
Although androgens are commonly seen as male sex hormones, it has been established over the years that in both sexes, androgens also respond to social challenges. To explain the socially driven changes in androgens, two theoretical models have been proposed: the biosocial model and the challenge hypothesis. These models are typically seen as partly overlapping; however, they generate different predictions that are clarified here. In humans, sports competition and nonmetabolic competitive tasks have been used in the laboratory setting, as a proxy for agonistic interactions in animals. The results reviewed here show that the testosterone $(\mathrm{T})$ response to competition in humans is highly variable - the studies present postcompetition $\mathrm{T}$ levels and changes in $\mathrm{T}$ that depend on the contest outcome and that cannot be predicted by the current theoretical models. These conflicting results bring to the foreground the importance of considering cognitive factors that could moderate the androgen response to competition. Among these variables, we elect cognitive appraisal and its components as a key candidate modulating factor. It is known that $\mathrm{T}$ also modulates the cognitive processes that are relevant to performance in competition. In this article, we reviewed the evidence arising from studies investigating the effect of administering exogenous $\mathrm{T}$ and compare those results with the findings from studies that measured endogenous T levels. Finally, we summarized the importance of also considering the interaction between androgens and other hormones, such as cortisol, when investigating the social modulation of $\mathrm{T}$, as proposed by the dual-hormone hypothesis.
\end{abstract}

Keywords: testosterone, challenge hypothesis, biosocial model, cognitive appraisal, cortisol

\section{Introduction}

Androgens have been traditionally viewed as sex steroids, involved in the organization of the nervous system in the early stages of development and in the activation of those neural systems in adulthood, reflecting sex differences in behavior. ${ }^{1}$ Although androgens, such as testosterone (T), are by definition male hormones, they are found in both sexes. In males, most of the circulating levels of T are produced by the Leydig cells in the testis, with the adrenal glands contributing a smaller part, ${ }^{2}$ and thus mainly reflect the activation of the hypothalamic-pituitary-gonadal axis. In contrast, in women, $\mathrm{T}$ is produced in equal parts by the adrenal zona fasciculata and the ovarian stroma, with $50 \%$ of the circulating levels of T resulting from the conversion of androstenedione. ${ }^{3,4}$ Apart from these peripheral endocrine sources, androgens are also produced centrally in the brain, either from the conversion of other circulating hormones or via de novo synthesis from cholesterol. ${ }^{5,6}$ Neurosteroids are known to be involved in sexual development and differentiation, and in the regulation of aggressive behavior, especially during the nonbreeding season. ${ }^{5}$ The research on neurosteroids in humans is limited
Correspondence: Rui F Oliveira

ISPA - Instituto Universitário,

R Jardim do Tabaco 34,

| |49-04| Lisboa, Portugal

Email ruiol@ispa.pt 
due to the invasive techniques involved, but these have already been linked to human depression and stress. ${ }^{7}$

In the last decades, it has been established that apart from their role as sex steroids, androgens also respond to the social environment, exerting androgen-dependent behaviors. ${ }^{8}$ This review aimed to discuss the research findings on the human androgen response to competition and the role of cognitive variables in modulating this response. For this purpose, we selected articles dealing with the $\mathrm{T}$ response to competitive tasks, using as an exclusion criteria, research that focused on the anabolic/catabolic processes resulting from physical effort. Since ultimately, the interaction between cognition and androgens is bidirectional, we also reviewed experiments linking androgens' levels to the psychological variables, which may clarify some of the results found in competition.

\section{The androgen response to competition}

Two hypotheses have been formally proposed to explain the response of androgens to the social environment: the biosocial model and the challenge hypothesis. The biosocial model, originally proposed by Mazur, suggests a relationship of mutually reinforcing feedback between $\mathrm{T}$ levels and social dominance. ${ }^{9,10}$ According to this model, individuals compete for status through contests; these contests activate the sympathetic nervous system (due to the stress associated with a competition) and elicit a differential $\mathrm{T}$ response that is congruent with the outcome of the contest. Therefore, dominant individuals are expected to have a higher baseline $\mathrm{T}$ and should respond to competition with a further increase in $\mathrm{T}$ after winning a contest, thus reinforcing their dominant behavior and facilitating the tendency to participate in future encounters. In contrast, subordinates are expected to have low initial $\mathrm{T}$ levels that should further drop after losing a contest, to inhibit status seeking behavior and further negative outcomes $^{9,10}$ - the role of T as a promoter of status-seeking behavior has received support in a recent review, ${ }^{11}$ although as other authors have pointed out, ${ }^{12}$ these effects cannot be dissociated from the moderating effects of sex, context, and the social environment.

Wingfield et al proposed the "challenge hypothesis", which aimed to explain the interspecific variation in androgen levels and the link between the reproductive and aggressive functions of T. ${ }^{13}$ According to this hypothesis, the increase in androgen levels from a nonbreeding, constitutive baseline to a breeding-season level (level A to level B in Figure 1) is sufficient for males to reproduce (ie, for spermatogenesis, expression of secondary sex characters, and reproductive behaviors),

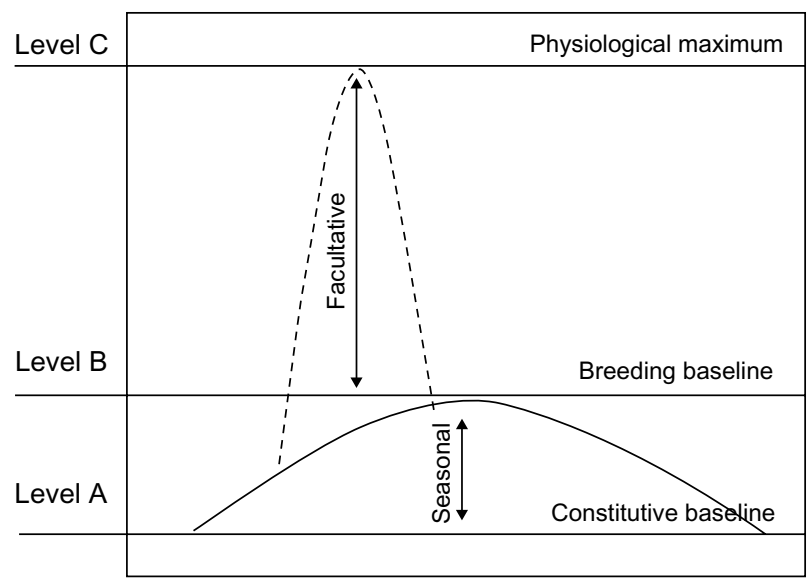

Figure I Schematic representation of androgen changes proposed by the challenge hypothesis: (A) constitutive androgen levels; (B) breeding baseline levels needed for successful reproduction; and (C) maximum physiological levels.

but further increases of T, toward a maximum physiological level (level C in Figure 1), reflect the social challenges faced by the males and are maintained only for the duration of the agonistic encounter. The challenge hypothesis was first advanced for birds, but it has been extended to other taxa, from invertebrates to humans. ${ }^{14-16}$ Although it was initially assumed by many authors that the predicted increases in $\mathrm{T}$ from "B" to " $\mathrm{C}$ " levels during the breeding season reflect the effect of social challenges, recently it has been shown that across different bird species, the seasonal androgen responsiveness is not correlated with the androgen responsiveness to experimental social challenges (eg, simulated territorial intrusions). ${ }^{17,18}$ The reviewed data suggest that the effect size of these responses to social challenges vary in magnitude and direction, depending on the species under observation; this in turn suggests that multiple factors contribute to the increases of $\mathrm{T}$ from $\mathrm{B}$ level to $\mathrm{C}$ level during the breeding season and that therefore, these $\mathrm{T}$ changes cannot be interpreted merely in function of the agonistic interactions that males are exposed to. ${ }^{17,18}$ The socially driven changes in $\mathrm{T}$ levels predicted by the challenge hypothesis have been seen as one mechanism that enables the individual to adjust the expression of its behavior according to the social context (eg, aggressive, parental, or sexual). By adjusting androgen production to social context, individuals are able not only to express flexible behavioral responses that fit the challenges, but also to avoid the fitness-decreasing costs (eg, increased metabolic rates, immunosuppression, and reduction of parental care) associated with chronically elevated concentrations of androgens. ${ }^{19-21}$

The two theoretical models described above generate different predictions for the T response to social challenges; 
however, they both stress its adaptive value, by allowing the adjustment of the motivational, behavioral, and cognitive processes of the individual to the perceived social environment, which in turn influences subsequent social interactions. The challenge hypothesis predicts the occurrence of a transient increase in $\mathrm{T}$ levels, which for the individuals involved in the agonistic encounter, cannot be equated to the increase from B level to $\mathrm{C}$ level without hypothesizing an outcomedependent (ie, differences between winners and losers) $\mathrm{T}$ change upon resolution of the interaction. The biosocial model explicitly predicts an anticipatory $\mathrm{T}$ increase in both opponents and a differential change in $\mathrm{T}$ as a function of the interaction outcome (ie, $\mathrm{T}$ postcompetition levels increase in winners and decrease in losers).

In many animal species, winning in agonistic encounters increases the individual probability of winning in future contests. ${ }^{22}$ Based on these findings a winner effect, mediated by the postcompetitive increase in androgen levels, has been proposed. ${ }^{23-26}$ The connection between the winner effect and androgens is supported by evidence from experimental research that manipulated the postcompetitive $\mathrm{T}$ pulse after a victory. These experiments demonstrated that winning a contest was not sufficient, per se, for the development of a winner effect, unless the victory was associated with an increment of T. ${ }^{26,27}$ In contrast, the loser effect that is also described in the literature (ie, animals that lose an aggressive interaction show a higher probability of losing future encounters) has not been shown to be androgen-dependent as the experimental increase of androgens after a loss was not sufficient to reverse it. ${ }^{26}$ Therefore, although functionally complementary, the winner and the loser effect seem to rely on different neuroendocrine mechanisms, and androgens seem to play a major role only in the former.

In humans, sports competition and contrived nonmetabolic demanding laboratory tasks have been used as a proxy for the agonistic encounters studied in animals (Table 1). Possibly because men have much higher circulating levels of $\mathrm{T}$ than do women and because in women, there is a need to account for additional sources of $\mathrm{T}$ variation (such as the phase of the menstrual cycle and the use of oral contraceptives), the early research on androgen responses to competition focused more on men. However, these potentially interfering variables have been the object of research, and it has been found that $\mathrm{T}$ levels are relatively stable across the menstrual cycle ${ }^{77,78}$ and that there are no significant effects of oral contraceptives on the pattern of T response to competition, despite that oral contraceptives (OC) users present with lower T levels. ${ }^{57}$ As a result, in recent years, the number of studies on the hormonal response to competition in women has increased significantly. Overall, these studies in human competition have shown an inconsistent pattern in both sexes, with $\mathrm{T}$ levels increasing in winners and decreasing in losers (as predicted by the biosocial model), increasing both in winners and losers, or not showing significant changes in response to the competitive event (see Table 1). These heterogeneous androgen responses to competition may reflect a mediation/moderation of the androgen response by cognitive variables, such as perceived threat/challenge, mood changes, etc. ${ }^{79,80}$ This interaction between cognitive processes and the androgen response is valid for both sexes and may help to explain some of the null findings reported in some female studies that had previously been attributed to differential androgen effects in women. ${ }^{81,82}$ Unexpected results have also been reported in male studies $^{41,67}$ and therefore, it is premature to downplay the role of $\mathrm{T}$ in women based on competition studies that did not find results according to the predictions of the theoretical models, especially since in women too, $\mathrm{T}$ has been linked to status and dominance, ${ }^{47,83-85}$ and shown to predict the reaction to winning and losing. ${ }^{49,54}$ Moreover, recent studies with females have shown a clear $\mathrm{T}$ response to competition in the direction predicted by the biosocial model, ${ }^{60,70}$ with no observed sex difference in the direction of the $\mathrm{T}$ response for winners and losers. ${ }^{70}$

The suggested interaction between cognitive processes and the triggering of the physiological response to competition should be seen as bidirectional, that is, not only do cognitive processes modulate the androgen response to competition but also, competition-driven changes in androgens affect subsequent cognitive processes that are relevant to competition for status and therefore, influence future interactions. ${ }^{9,10,86}$ For example, the $\mathrm{T}$ increase after a social challenge has been found to be a predictor of dominance and willingness to engage in competitive interactions even after losing a previous competition, and has also been linked to choosing aggression instead of behaviors that lead to economic rewards. ${ }^{49,53,56,63,87}$ Interestingly the behavioral effects of these heightened $\mathrm{T}$ levels are not necessarily associated with winning the interaction, which is contrary to what would be predicted by the biosocial model (ie, losers increase T; no effect of the perceived outcome). ${ }^{49,53}$

In summary, the adaptive function of the androgen changes in response to competitive interactions seems to be related to the adjustment of cognitive and physical parameters 
Table I Summary of human studies reporting effects of competition on androgen levels (sorted by year of publication)

\begin{tabular}{|c|c|c|c|c|c|c|c|}
\hline Author & Paradigm & $\operatorname{Sex}(n)$ & Measure & $\begin{array}{l}\text { Competition } \\
\text { effect }\end{array}$ & $\begin{array}{l}\text { Winner vs } \\
\text { loser }\end{array}$ & $\begin{array}{l}\text { Pre vs post } T \\
\text { winner }\end{array}$ & $\begin{array}{l}\text { Pre vs post T } \\
\text { loser }\end{array}$ \\
\hline \multirow[t]{2}{*}{ Mazur and Lamb ${ }^{28}$} & Tennis & $M(8)$ & Plasma & $\downarrow$ (close match) & $\mathrm{n} / \mathrm{a}$ & $\uparrow$ (decisive match) & $\downarrow$ (decisive match) \\
\hline & Lottery & $M(14)$ & Plasma & ns & $\mathrm{n} / \mathrm{a}$ & ns & ns \\
\hline \multirow[t]{2}{*}{ Elias $^{29}$} & Wrestling & $M(15)$ & Plasma & $\uparrow$ & $W>L$ & $\mathrm{n} / \mathrm{a}$ & $\mathrm{n} / \mathrm{a}$ \\
\hline & & & & & (T\% change) & & \\
\hline Booth et $\mathrm{al}^{30}$ & Tennis & $M(6)$ & Saliva & $\mathrm{n} / \mathrm{a}$ & ns & $\mathrm{n} / \mathrm{a}$ & $\mathrm{n} / \mathrm{a}$ \\
\hline Gladue et $\mathrm{al}^{31}$ & Reaction time task & M (39) & Saliva & $\mathrm{n} / \mathrm{a}$ & $W>L$ & $\mathrm{n} / \mathrm{a}$ & $\mathrm{n} / \mathrm{a}$ \\
\hline \multirow[t]{2}{*}{ Mazur et $\mathrm{al}^{32}$} & Chess regional & $M(8)$ & Saliva & $\mathrm{n} / \mathrm{a}$ & $W>L$ & $\mathrm{n} / \mathrm{a}$ & $\mathrm{n} / \mathrm{a}$ \\
\hline & Chess tournament & $M(8)$ & Saliva & $\mathrm{n} / \mathrm{a}$ & $W>L$ & $\mathrm{n} / \mathrm{a}$ & $\mathrm{n} / \mathrm{a}$ \\
\hline \multirow[t]{3}{*}{ McCaul et al $\left.\right|^{33}$} & Exp 1: coin toss & $M(28)$ & Saliva & $\mathrm{n} / \mathrm{a}$ & $W>L$ & $\mathrm{n} / \mathrm{a}$ & $\mathrm{n} / \mathrm{a}$ \\
\hline & & & & & $(P=0.079)$ & $\mathrm{n} / \mathrm{a}$ & $\mathrm{n} / \mathrm{a}$ \\
\hline & Exp 2: coin toss & $M(10 I)$ & Saliva & $\mathrm{n} / \mathrm{a}$ & $W>L$ & & \\
\hline \multirow[t]{2}{*}{ Mazur et al ${ }^{14}$} & Video game & $M(28)$ & Saliva & ns & ns & $\mathrm{n} / \mathrm{a}$ & $\mathrm{n} / \mathrm{a}$ \\
\hline & & $F(32)$ & Saliva & $\downarrow$ & ns & $\mathrm{n} / \mathrm{a}$ & $\mathrm{n} / \mathrm{a}$ \\
\hline \multirow[t]{2}{*}{ Bernhardt et al ${ }^{35}$} & Watching basketball & $M(8)$ & Saliva & $\mathrm{n} / \mathrm{a}$ & $\mathrm{n} / \mathrm{a}$ & $\uparrow$ & $\downarrow$ \\
\hline & Watching soccer & $M(2 I)$ & Saliva & $\mathrm{n} / \mathrm{a}$ & $\mathrm{n} / \mathrm{a}$ & $\uparrow$ & $\downarrow$ \\
\hline Gonzalez-Bono et a $\left.\right|^{36}$ & Basketball & $M(16)$ & Saliva & $\mathrm{n} / \mathrm{a}$ & ns & ns & ns \\
\hline Schultheiss et $\mathrm{al}^{37}$ & NTT & $M(42)$ & Saliva & $\mathrm{n} / \mathrm{a}$ & ns & $\mathrm{n} / \mathrm{a}$ & $\mathrm{n} / \mathrm{a}$ \\
\hline Suay et $\left.a\right|^{38}$ & Judo & $M(28)$ & Plasma & $\uparrow$ & ns & $\mathrm{n} / \mathrm{a}$ & $\mathrm{n} / \mathrm{a}$ \\
\hline Gonzalez-Bono & Basketball & $M(16)$ & Saliva & $\mathrm{n} / \mathrm{a}$ & $\mathrm{n} / \mathrm{a}$ & Team I: $\uparrow(P=0.058)$ & $\mathrm{n} / \mathrm{a}$ \\
\hline et $\mathrm{al}^{39}$ & (winners) & & & & & Team 2: ns & \\
\hline Serrano et $\mathrm{a}^{40}$ & Judo & $M(12)$ & Saliva & ns & ns & ns & ns \\
\hline Filaire et $\mathrm{al}^{41}$ & Judo & $M(18)$ & Saliva & $\mathrm{n} / \mathrm{a}$ & $\mathrm{W}<\mathrm{L}$ & ns & ns \\
\hline Bateup et $\mathrm{al}^{42}$ & Rugby & $F(I 7)$ & Saliva & $\uparrow$ & ns & $\mathrm{n} / \mathrm{a}$ & $\mathrm{n} / \mathrm{a}$ \\
\hline Schultheiss and Rohde ${ }^{43}$ & NTT & $M(66)$ & Saliva & $\mathrm{n} / \mathrm{a}$ & ns & $\mathrm{n} / \mathrm{a}$ & $\mathrm{n} / \mathrm{a}$ \\
\hline Wagner et $\mathrm{al}^{44}$ & Domino & $M(8)$ & Saliva & $\mathrm{n} / \mathrm{a}$ & ns & ns & ns \\
\hline \multirow[t]{2}{*}{ Kivlighan et $\mathrm{a}^{45}$} & Ergometer & $M(23)$ & Saliva & $\uparrow$ & $\mathrm{n} / \mathrm{a}$ & $\mathrm{n} / \mathrm{a}$ & $\mathrm{n} / \mathrm{a}$ \\
\hline & & $F(23)$ & Saliva & ns & $\mathrm{n} / \mathrm{a}$ & $\mathrm{n} / \mathrm{a}$ & $\mathrm{n} / \mathrm{a}$ \\
\hline \multirow[t]{2}{*}{ Schultheiss et a ${ }^{46}$} & SRT task & $M(95)$ & Saliva & $\mathrm{n} / \mathrm{a}$ & $\mathrm{n} / \mathrm{a}$ & $\mathrm{n} / \mathrm{a}$ & $\mathrm{n} / \mathrm{a}$ \\
\hline & & $F(75)$ & Saliva & $\mathrm{n} / \mathrm{a}$ & $\mathrm{n} / \mathrm{a}$ & $\mathrm{n} / \mathrm{a}$ & $\mathrm{n} / \mathrm{a}$ \\
\hline \multirow[t]{2}{*}{ Edwards et al ${ }^{47}$} & Soccer & $M(22)$ & Saliva & $\mathrm{n} / \mathrm{a}$ & $\mathrm{n} / \mathrm{a}$ & $\uparrow(P=0.08)$ & $\mathrm{n} / \mathrm{a}$ \\
\hline & & $F(18)$ & Saliva & $\mathrm{n} / \mathrm{a}$ & $\mathrm{n} / \mathrm{a}$ & $\uparrow$ & $\uparrow$ \\
\hline Josephs et $\mathrm{al}^{48}$ & NTT & $M(92)$ & Saliva & $\mathrm{n} / \mathrm{a}$ & $\mathrm{n} / \mathrm{a}$ & $\mathrm{n} / \mathrm{a}$ & $\mathrm{n} / \mathrm{a}$ \\
\hline Mehta and Josephs ${ }^{49}$ & NTT & $M(64)$ & Saliva & $\mathrm{n} / \mathrm{a}$ & $\mathrm{n} / \mathrm{a}$ & $\mathrm{n} / \mathrm{a}$ & $\mathrm{n} / \mathrm{a}$ \\
\hline Parmigiani and & Judo & $M(22)$ & Plasma & $\uparrow($ total T) & $\mathrm{W}<\mathrm{L}$ & $\mathrm{n} / \mathrm{a}$ & $\mathrm{n} / \mathrm{a}$ \\
\hline Bartolomucci ${ }^{50}$ & & & & & $\begin{array}{l}\text { (free and } \\
\text { total T) }\end{array}$ & & \\
\hline Stanton and Schultheiss ${ }^{51}$ & ' SRT & $\mathrm{F}(49)$ & Saliva & $\mathrm{n} / \mathrm{a}$ & $\mathrm{n} / \mathrm{a}$ & $\mathrm{n} / \mathrm{a}$ & $\mathrm{n} / \mathrm{a}$ \\
\hline Van Anders and & Vocabulary task & $M(37)$ & Saliva & $\mathrm{n} / \mathrm{a}$ & ns & ns & $\downarrow(P=0.055)$ \\
\hline \multirow[t]{3}{*}{ Watson $^{52}$} & (ability determined) & $F(38)$ & Saliva & $\mathrm{n} / \mathrm{a}$ & ns & ns & ns \\
\hline & Vocabulary task & $M(3 I)$ & Saliva & ns & ns & ns & ns \\
\hline & (chance determined) & $F(43)$ & Saliva & ns & ns & ns & ns \\
\hline Carré and $\mathrm{McCormick}{ }^{53}$ & PSAP & $M(38)$ & Saliva & $\uparrow$ & $\mathrm{n} / \mathrm{a}$ & $\mathrm{n} / \mathrm{a}$ & $\mathrm{n} / \mathrm{a}$ \\
\hline \multirow[t]{3}{*}{ Mehta et al ${ }^{45}$} & Dog competition & $M(93)$ & Saliva & $\mathrm{n} / \mathrm{a}$ & $\mathrm{n} / \mathrm{a}$ & $\mathrm{n} / \mathrm{a}$ & $\mathrm{n} / \mathrm{a}$ \\
\hline & & $F(9 I)$ & & & & & \\
\hline & Intelligence test & $\mathrm{F}(70)$ & Saliva & $\mathrm{n} / \mathrm{a}$ & $\mathrm{n} / \mathrm{a}$ & $\mathrm{n} / \mathrm{a}$ & $\mathrm{n} / \mathrm{a}$ \\
\hline Carré$^{55}$ & Hockey (winners) & $M(10)$ & Saliva & $\mathrm{n} / \mathrm{a}$ & $\mathrm{n} / \mathrm{a}$ & $\uparrow$ & $\mathrm{n} / \mathrm{a}$ \\
\hline \multirow[t]{2}{*}{ Carré et a $\left.\right|^{56}$} & NTT + PSAP & M (39) & Saliva & $\downarrow$ & $\mathrm{n} / \mathrm{a}$ & $\mathrm{n} / \mathrm{a}$ & $\mathrm{n} / \mathrm{a}$ \\
\hline & & $F(60)$ & Saliva & $\downarrow$ & $\mathrm{n} / \mathrm{a}$ & $\mathrm{n} / \mathrm{a}$ & $\mathrm{n} / \mathrm{a}$ \\
\hline Edwards and $\mathrm{O}^{\prime} \mathrm{Nea}^{57}$ & Sports & $F(80)$ & Saliva & $\uparrow$ & $\mathrm{n} / \mathrm{a}$ & $\mathrm{n} / \mathrm{a}$ & $\mathrm{n} / \mathrm{a}$ \\
\hline Hamilton et al ${ }^{58}$ & Wrestling & $F(2 I)$ & Saliva & $\mathrm{n} / \mathrm{a}$ & ns & $\uparrow$ & $\uparrow$ \\
\hline \multirow[t]{2}{*}{ Mehta et a ${ }^{59}$} & Intelligence test & $M(30)$ & Saliva & $\mathrm{n} / \mathrm{a}$ & $\mathrm{n} / \mathrm{a}$ & $\mathrm{n} / \mathrm{a}$ & $\mathrm{n} / \mathrm{a}$ \\
\hline & & $F(30)$ & & & & & \\
\hline Oliveira et $\mathrm{a}^{60}$ & Soccer & F (33) & Saliva & $\mathrm{n} / \mathrm{a}$ & $W>L$ & $\uparrow$ & $\downarrow$ \\
\hline Pound et $\mathrm{al}^{61}$ & Lab task & $M(57)$ & Saliva & $\mathrm{n} / \mathrm{a}$ & $W>L$ & $\uparrow$ & ns \\
\hline
\end{tabular}


Table I (Continued)

\begin{tabular}{|c|c|c|c|c|c|c|c|}
\hline Author & Paradigm & $\operatorname{Sex}(n)$ & Measure & $\begin{array}{l}\text { Competition } \\
\text { effect }\end{array}$ & $\begin{array}{l}\text { Winner vs } \\
\text { loser }\end{array}$ & $\begin{array}{l}\text { Pre vs post } T \\
\text { winner }\end{array}$ & $\begin{array}{l}\text { Pre vs post } \mathbf{T} \\
\text { loser }\end{array}$ \\
\hline \multirow[t]{2}{*}{ Stanton et $\mathrm{al}^{62}$} & Elections & $M(57)$ & Saliva & $\mathrm{n} / \mathrm{a}$ & $W>L$ & ns & $\downarrow$ \\
\hline & & $F(106)$ & Saliva & $\mathrm{n} / \mathrm{a}$ & ns & $\mathrm{n} / \mathrm{a}$ & $\mathrm{n} / \mathrm{a}$ \\
\hline Carre et $\mathrm{al}^{63}$ & PSAP & $M(139)$ & Saliva & ns & $\mathrm{n} / \mathrm{a}$ & $\mathrm{n} / \mathrm{a}$ & $\mathrm{n} / \mathrm{a}$ \\
\hline \multicolumn{2}{|c|}{ Edwards and Kurlander ${ }^{64}$ Volleyball (winners) } & $F(15)$ & Saliva & $\mathrm{n} / \mathrm{a}$ & $\mathrm{n} / \mathrm{a}$ & $\uparrow$ & $\mathrm{n} / \mathrm{a}$ \\
\hline & Tennis (losers) & $F(13)$ & Saliva & $\mathrm{n} / \mathrm{a}$ & $\mathrm{n} / \mathrm{a}$ & $\mathrm{n} / \mathrm{a}$ & $\uparrow$ \\
\hline Oxford et al ${ }^{65}$ & Video game (teams) & $M(42)$ & Saliva & $\mathrm{n} / \mathrm{a}$ & $\mathrm{n} / \mathrm{a}$ & $\begin{array}{l}\uparrow \text { (between teams } \\
\text { competition) }\end{array}$ & $\begin{array}{l}\uparrow \text { (between teams } \\
\text { competition) }\end{array}$ \\
\hline Steiner et $\mathrm{al}^{66}$ & Poker & $M(32)$ & Saliva & $\mathrm{n} / \mathrm{a}$ & ns & $\uparrow$ & $\uparrow$ \\
\hline Van der Meij et $a^{67}$ & Intelligence test & $M(84)$ & Saliva & $\mathrm{n} / \mathrm{a}$ & ns & $\uparrow$ & $\uparrow$ \\
\hline Slatcher et $\mathrm{al}^{68}$ & Lab task & $M(76)$ & Saliva & $\mathrm{n} / \mathrm{a}$ & $\mathrm{n} / \mathrm{a}$ & $\mathrm{n} / \mathrm{a}$ & $\mathrm{n} / \mathrm{a}$ \\
\hline Costa and Salvador ${ }^{69}$ & Squares and letters & $F(40)$ & Saliva & $\mathrm{n} / \mathrm{a}$ & $W>L$ & $\mathrm{n} / \mathrm{a}$ & $\mathrm{n} / \mathrm{a}$ \\
\hline \multirow[t]{2}{*}{ Jiménez et $\mathrm{al}^{70}$} & Badminton & $M(27)$ & Saliva & $\mathrm{n} / \mathrm{a}$ & $W>L$ & $\uparrow$ & $\downarrow$ \\
\hline & & $F(23)$ & Saliva & $\mathrm{n} / \mathrm{a}$ & $W>L$ & $\uparrow$ & $\downarrow$ \\
\hline Trumble et $\mathrm{al}^{71}$ & Soccer & $M(88)$ & Saliva & $\uparrow$ & ns & $\mathrm{n} / \mathrm{a}$ & $\mathrm{n} / \mathrm{a}$ \\
\hline \multirow[t]{2}{*}{ Van der Meij et $\mathrm{al}^{72}$} & Watching soccer & $M(25)$ & Saliva & $\mathrm{n} / \mathrm{a}$ & $\mathrm{n} / \mathrm{a}$ & ns & $\mathrm{n} / \mathrm{a}$ \\
\hline & (winners) & $F(25)$ & Saliva & $\mathrm{n} / \mathrm{a}$ & $\mathrm{n} / \mathrm{a}$ & ns & $\mathrm{n} / \mathrm{a}$ \\
\hline Zilioli and Watson ${ }^{73}$ & Tetris & $M(70)$ & Saliva & $\mathrm{n} / \mathrm{a}$ & $W>L$ & ns & $\downarrow$ \\
\hline \multirow[t]{2}{*}{ Carré et $\mathrm{al}^{74}$} & Video game & $M(I \mid 4)$ & Saliva & $\mathrm{n} / \mathrm{a}$ & $W>L$ & $\mathrm{n} / \mathrm{a}$ & $\mathrm{n} / \mathrm{a}$ \\
\hline & & $F(123)$ & Saliva & $\mathrm{n} / \mathrm{a}$ & ns & $\mathrm{n} / \mathrm{a}$ & $\mathrm{n} / \mathrm{a}$ \\
\hline Denson et $\mathrm{al}^{75}$ & RT task & $F(53)$ & Saliva & $\mathrm{n} / \mathrm{a}$ & $W>L$ & $\mathrm{n} / \mathrm{a}$ & $\mathrm{n} / \mathrm{a}$ \\
\hline Oliveira et $\mathrm{al}^{76}$ & NTT & $F(34)$ & Saliva & $\mathrm{n} / \mathrm{a}$ & $\begin{array}{l}W<L \\
(P=0.097)\end{array}$ & ns & $\uparrow$ \\
\hline
\end{tabular}

Notes: $\downarrow=$ significant decrease; $\uparrow=$ significant increase.

Abbreviations: F, female; L, loser; M, male; n/a, not tested in original paper; ns, nonsignificant differences; NTT, number tracking test; PSAP, point subtraction aggression paradigm; SRT, serial response task; T, testosterone; W, winner; vs, versus; Pre, pre-competition levels of T; post, post-competition levels of T; Exp, experiment; Lab, laboratory; RT, reaction time.

that help modulate subsequent behavior, according to perceived social status and social context.

\section{Psychological moderators and mediators of androgen response to competition}

The proposed interaction between the physiological response and cognitive cues can already be found in the biosocial model. ${ }^{9,86}$ Among the suggested modulators of the T response to competition, cognitive appraisal has been mentioned as a major candidate since it is known to be a key mechanism in the activation of the physiological response to challenges in animals and humans ${ }^{80,88}$ (Figure 2). According to this idea, it is not only the intrinsic characteristics of the social interaction that trigger a physiological response but rather, the evaluation of what that event means to that organism at that moment in time. As a consequence, the same exact event may elicit different responses, depending on the way it is appraised by different individuals or by the same individual at different moments in time (eg, in different social contexts).

According to Lazarus, one of the founders of the appraisal theory, two major types of appraisal occur: a) primary appraisal, which evaluates the significance of the event to the organism; and b) secondary appraisal, which assesses the ability of the organism to cope with the perceived consequences of the event. ${ }^{89}$ These two types of appraisal interact with each other in defining the outcome of an appraisal, which can be a direct action or a cognitive reappraisal process. More recently, Scherer defined appraisal as a set of stimulus evaluation checks - including dimensions such as suddenness, familiarity, predictability, intrinsic pleasantness, discrepancy from expectation, and capacity for control - that subjects use to assess stimuli/ events in order to activate a response. ${ }^{90}$ These stimulus evaluation checks can be understood as elements of the two processes proposed by Lazarus, ${ }^{89}$ with the intrinsic valence, novelty (defined by the components of suddenness, familiarity, and predictability), and prediction error related to primary appraisal and controllability to secondary appraisal. The influence of cognitive appraisal on the activation of the androgen response to competitive interactions was first highlighted in an experiment with cichlid fish, which showed that males that engaged in ambiguous fights (ie, fighting their own image on a mirror and therefore, 


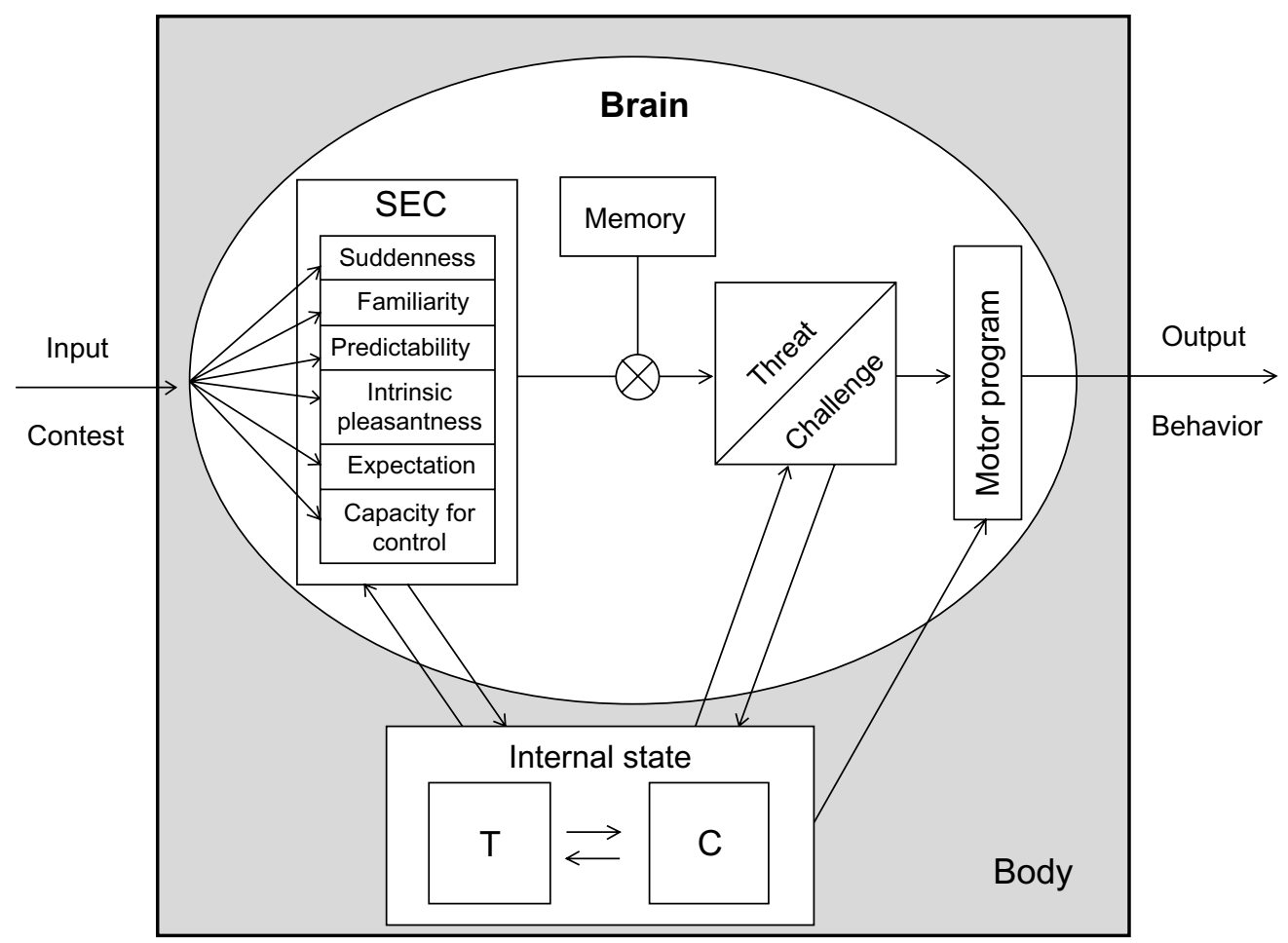

Figure 2 Hypothetical representation of the interaction between hormones and cognition, from contest appraisal to behavioral response. Abbreviations: C, cortisol; SEC, stimulus evaluation checks; T, testosterone.

without information on the outcome of the interaction) did not exhibit the androgen response observed in males fighting real opponents. ${ }^{91}$ These data, along with other experiments, suggest that the expression of aggression is not sufficient, per se, to increase androgen levels, and that animals need to assess social information about the interaction outcome and/or social context in order to trigger an androgen response. ${ }^{92,93}$ Evidence for the effect of opponent appraisal in human competition was demonstrated by Van der Meij et al, in an experiment using a cognitive laboratory task. This study found a connection between increases of $\mathrm{T}$ after the competition and opponent selfefficacy, indicating that the information gathered about the opponent was used to adjust the endocrine response. ${ }^{67}$ This hypothesis is also congruent with the abovementioned role of appraisal and opponent assessment in animal agonistic encounters. ${ }^{91-93}$ In sports, there is also some evidence for the effects of cognitive appraisal on $T$ response, mostly related to the causal attribution of the competition outcome, which can be interpreted as part of the implication-assessment component of cognitive appraisal. ${ }^{89}$ The association between postmatch $\mathrm{T}$ and external attribution of the competition outcome has been reported as being negative for winners and positive for losers, ${ }^{36,39}$ while another study found no hormonal differences when the sample was split by appraisal of performance and satisfaction with the outcome. ${ }^{38}$ The effects of some specific dimensions of appraisal on the androgen response to competition have already been investigated and will be discussed below.

\section{Familiarity with location and opponent}

Some results from human experiments suggest that men have higher $\mathrm{T}$ levels before matches taking place at their home venue than at away venues and also that these higher T levels are associated with higher team rivalry. ${ }^{94,95}$ Yet another study showed that a home field victory led to higher postgame $\mathrm{T}$ than when victory was achieved at the opponent's venue, but the aforementioned effect of game location on pregame $\mathrm{T}$ levels was not found. ${ }^{55}$ The same authors proposed that the absence of this effect could be due to the sample, which consisted of amateur rather than elite players.

The identified connection between territorial behavior and team rivalry also brings into question what role is played by the individual group membership when facing a dominance contest. Early evidence of the moderating effect of group membership was found in a domino competition between neighboring Caribbean villages. In this study, the teams competed against familiar men and also against strangers, and although the effect did not reach statistical significance, $\mathrm{T}$ tended to increase more before matches against neighboring 
villages than against teams of their own village. ${ }^{44}$ Trumble et al organized a soccer tournament among the Amazonian Tsimané and attributed the lack of a winning effect on $\mathrm{T}$ response to the interference of in-group factors arising from a relative acquaintance between players of the opposing teams. ${ }^{71}$ Familiarity itself can also be seen as an early component in the process of cognitive appraisal. ${ }^{90}$ In a recent competition experiment involving women, participants who lost the competition had higher T levels than did the winners. This $\mathrm{T}$ response was moderated by both the appraisal of the competition as a threat and the degree of familiarity with the opponent, with unfamiliar opponents and higher threat appraisal predicting a higher $\mathrm{T}$ response. ${ }^{76}$

Perhaps the clearest effect of group membership on the $\mathrm{T}$ response to competition can be found in a study by Oxford et al that used a video game tournament, with teams competing against each other (between groups) and also, team members competing against their own team mates (within group). ${ }^{65}$ Among the findings of this experiment, Oxford et al showed that men who contributed more to the team score, and thus considered as high ranking, had a $\mathrm{T}$ response that was different between in-group and out-group competition. ${ }^{65}$ The high-ranking winners had a higher $\mathrm{T}$ after the match when the between-groups competition was played first, but high-ranking players showed a lower $\mathrm{T}$ and higher cortisol (C), independently of winning or losing the match, in the within-group competition. ${ }^{65}$

\section{Individual characteristics}

Besides the social and cognitive variables proposed as modulators of socially-driven androgen responses, individual characteristics have also been proposed to play some role in the endocrine response to competition. Power-motivated individuals use assertiveness to achieve an impact on others, while obtaining reward and reinforcement from those actions. Thus, implicit power motivation predicts many dominance behaviors with which high $\mathrm{T}$ is usually associated. ${ }^{96}$ Experiments using a contrived competitive task showed that individuals with high power motivation had the highest $\mathrm{T}$ levels after winning, but no association was found between personalized power and high $\mathrm{T}$ for losers. ${ }^{37}$ Furthermore, high implicit power motivation predicted stronger increases of $\mathrm{T}$ postcontest for male winners with low activity inhibition (used as a measure of impulse control) and also enhanced implicit learning. ${ }^{43}$ Sex differences and similarities for the effect of implicit power motivation on $\mathrm{T}$ have also been reported. ${ }^{46}$ In these experiments, high implicit power motivation predicted increases of $\mathrm{T}$ after the contest for men and women in the winner condition, but the $\mathrm{T}$ response in the loser condition was moderated by sex, where power motive was a negative predictor of $\mathrm{T}$ for men and a positive predictor of $\mathrm{T}$ for women. ${ }^{46}$ This finding of women who showed increased $\mathrm{T}$ after losing a competition has been interpreted as readiness to reengage in competition, after the power goal was not achieved. ${ }^{46}$

\section{Effects of androgens on physiological parameters relevant to performance in competition}

$\mathrm{T}$ and synthetic derivatives of $\mathrm{T}$ are commonly used to enhance athletic performance. ${ }^{97-99}$ Although androgenicanabolic steroid (AAS) action may occur through different mechanisms, due to molecular variations and different androgen receptor affinities, ${ }^{97}$ AAS or T supplementation leads to an alteration in the physiology of skeletal muscle, increasing the number of myonuclei in muscle fibers and the number of satellite cells in muscle tissue. ${ }^{97,98}$ Thus, AASs may lead to an increase in body dimensions and body weight, consistent with results from nonhuman animals. ${ }^{98}$ However, as pointed out in recent reviews, ${ }^{97,98,100}$ there are many contradictory results that can be attributed to differences in the type of AAS used, the dosage, and the duration of use. In humans, enhanced physical performance as a consequence of T supplementation seems to be restricted to strength and sprint tasks, either due to increased muscle mass or changes in the contractile properties of the muscle, and no effects have been reported for endurance tasks. ${ }^{98}$

\section{Effects of androgens on psychological parameters relevant to performance in competition}

Sex steroids can modulate perceptional, motivational, and cognitive processes by binding to either androgen or to estrogen receptors (some of the behavioral effects of $\mathrm{T}$ require aromatization of this hormone to estradiol) that have been found in the brain areas directly involved in these functions. ${ }^{8}$ The availability of noninvasive $\mathrm{T}$ administration techniques (ie, oral and dermal) for human participants allowed the proliferation of studies that aimed to investigate the effects of $\mathrm{T}$ in psychological parameters. The effects of $\mathrm{T}$ on human cognition have also been investigated, using endogenous baseline measures of $\mathrm{T}$ or via environmental manipulations that induced a change in androgen levels within the physiological range of the individual. Results from these experiments should be compared with those arising from paradigms involving exogenous administration of 
$\mathrm{T}$ - with exogenous administration of $\mathrm{T}$, the dose-response curve follows an inverted U-function, and this procedure may lead to pharmacologically induced supraphysiological hormone levels. ${ }^{101}$

Given the importance of $\mathrm{T}$ in social challenges, experiments were planned to investigate the relationship between $\mathrm{T}$ and the variables involved in threat detection. In a social environment, the rapid detection of threatening stimuli is critical for survival, and the presence of an efficient threat detection system can be seen as an evolutionary adaptive advantage since it allows the appropriate selection of a fightor-flight response. Research shows that there is an automatic attentional bias toward threat stimuli and that anxiety and vigilant behavior play a role in this effect. ${ }^{102,103}$ The fearreducing properties of $\mathrm{T}$ have already been demonstrated in animals, ${ }^{104,105}$ and the convergence of experiments using different paradigms suggests that this $\mathrm{T}$ effect on fear is also present for humans. Participants who had their levels of $\mathrm{T}$ experimentally increased showed a decreased unconscious vigilant emotional response to masked fearful faces when compared with a placebo group, but $\mathrm{T}$ had no effect on selfreported measures of anxiety. ${ }^{106}$ Furthermore, exogenous $\mathrm{T}$ reduced the fear-potentiated startle reflex and lowered the electrodermal response to negative stimuli (which can be interpreted as an attenuation of the sympathetic components of the stress response), ${ }^{107}$ especially in participants with initial high-anxiety and high-reactivity to affective startle modulation. ${ }^{108}$

The facial expression of anger has been interpreted as a threat signal. In an experiment that used a morphing neutral to emotional stimuli paradigm, $\mathrm{T}$ administration reduced the sensitivity to consciously detected angry faces. ${ }^{109}$ When viewed together with previous research, these experiments suggest that the impaired unconscious threat perception, as measured by decreased selective attention to threatening faces after administration of $\mathrm{T}$, might be mediated by the fear reduction properties of $\mathrm{T}^{106-108}$ Moreover, social aggression may be facilitated by other effects of $\mathrm{T}$, for example, it has been found to increase the cardiac response in participants exposed to angry faces. This can be seen as readiness to aggressively engage in status contests ${ }^{110}$ and to increase risktaking behavior, while also increasing reward and lowering punishment sensitivity. ${ }^{11}$

In all the studies mentioned above, $\mathrm{T}$ was increased to supraphysiological levels and only female participants were included; however, Wirth and Schultheiss found similar patterns with endogenous $\mathrm{T}$ in men and women. In this study, ${ }^{85}$ basal morning $\mathrm{T}$ levels were related to a greater interference with supraliminal angry faces, in an emotional Stroop task, congruent with previous research. ${ }^{112,113} \mathrm{~T}$ also predicted an attentional bias away from angry faces, in a dot-probe task, ${ }^{85}$ consistent with the anxiolytic effect of T. ${ }^{106-108}$ Raising androgens to supraphysiological levels has also been shown to affect interpersonal factors. In fact, $T$ downregulated interpersonal trust in overtrusting individuals, preparing them for possible competition for status and resources, ${ }^{114}$ and reduced facial mimicry, a critical function in communicating empathy toward conspecifics. ${ }^{115}$ Furthermore, sublingual $\mathrm{T}$ administration induced a marked impairment on the Reading the Mind in the Eyes Task (RMET), a test that has been used as a measure of social intelligence and cognitive empathy; however, this effect was only found in individuals with high fetal exposure to $\mathrm{T}$, as measured using the ratio of the length of the second and fourth finger of the right hand (2D:4D) as a marker of fetal exposure to androgens. ${ }^{116}$ These results should be noted with caution since it is still questionable whether the $2 \mathrm{D}: 4 \mathrm{D}$ finger index is a valid biomarker of prenatal androgen exposure. For example, women with complete androgen insensitivity syndrome have still shown feminized 2D:4D ratios despite the ineffective androgen exposure in utero. ${ }^{117}$

\section{Functional neuroimaging evidence for the action of androgens in psychological parameters}

Recently, studies that have employed functional magnetic resonance imaging (fMRI) helped to shed light on 1) how the endocrine system interacts with target brain areas when individuals are presented with threatening stimuli and on 2) how the changes in neural activity may explain the relation between hormones and behavior. Hermans et al showed that female participants with high $\mathrm{T}$ and $\mathrm{C}$ have a stronger subcortical response to social threat and that after $\mathrm{T}$ administration, there is a greater activation of the amygdala and the hypothalamus than occurs following the administration of placebo. ${ }^{118}$ The administration of $\mathrm{T}$ to middle-aged women with an age-related decrease in androgen levels restored the amygdala activation in response to threatening stimuli to the levels found in younger women, thus providing further data in support of the regulation of amygdala activity by $\mathrm{T} .{ }^{119}$ Studies with endogenous $\mathrm{T}$ are congruent with the findings described above and have also found a positive association between $\mathrm{T}$ and amygdala activation that is specific to angry and fearful faces. ${ }^{120,121}$ However, differences in amygdala reactivity have been found to depend on the variation in length of the trinucleotide cytosine-adenine-guanine 
$(\mathrm{CAG})$ in the androgen receptor gene. It has been found that the activation of the dorsal amygdala was not affected by the number of $\mathrm{CAG}$ repeats, but a high number of $\mathrm{CAG}$ repeats was associated with low ventral amygdala reactivity (when corrected for salivary $T$ levels), suggesting that the androgen effect on the activation of this area of the amygdala may be moderated by variations in the length of CAG in the androgen receptor gene. ${ }^{121}$

The orbitofrontal cortex (OFC), a brain region involved in impulse control and emotional regulation that is functionally and anatomically connected with the amygdala, has also been identified as a possible moderator of the effect of $\mathrm{T}$ in amygdala reactivity. ${ }^{122,123}$ After $\mathrm{T}$ administration to women, participants showed a reduced functional connectivity between the amygdala and the OFC, suggesting that $\mathrm{T}$ may reduce the inhibitory control of the OFC over the amygdala. ${ }^{124}$ This finding is also congruent with a previous experiment that measured endogenous $\mathrm{T}$ in men and women and found that the effect of $\mathrm{T}$ on aggression was mediated by the activity of the $\mathrm{OFC}$, with $\mathrm{T}$ increasing the propensity for aggressive behavior, due to reduced activation of the OFC. ${ }^{125}$

Evidence has also been found for the effects of T in motivational and reward circuits. It has been shown that $T$ activates the mesolimbic dopaminergic circuits involved in reinforcement regulation and incentive processing. In one study, female participants with low intrinsic motivation showed an increased activation of the ventral striatum (a target area of the mesolimbic dopaminergic system) in anticipation of a reward after $\mathrm{T}$ administration, while those with high motivation showed no further enhancement by T. ${ }^{126}$

\section{Effects of androgens in spatial abilities}

Performance in spatial abilities tasks has been linked to higher levels of androgens. Since men have higher concentrations of $\mathrm{T}$ than women, it has been suggested that $\mathrm{T}$ could partly explain the sex differences observed in spatial ability tasks. ${ }^{127}$ Indeed, some studies have reported an association between endogenous levels of $\mathrm{T}$ and enhanced spatial abilities in younger and older men, ${ }^{128-130}$ but other studies have failed to find this association. ${ }^{131-133}$ It has been reported that when the circulating levels of $\mathrm{T}$ were experimentally increased, a selective effect of $\mathrm{T}$ was observed on specific parameters of spatial memory that were involved in the location of objects displayed on a screen, with $\mathrm{T}$ enhancing performance. ${ }^{134}$ In another experiment, after controlling for the learning effects from repeated testing, participants showed an increased visuospatial ability after $\mathrm{T}$ administration compared with participants receiving placebo. ${ }^{135}$ There is also evidence that $\mathrm{T}$ supplementation increased spatial memory in older men, ${ }^{136,137}$ but increasing $\mathrm{T}$ to supraphysiological levels in eugonadal males has also led to a worse spatial performance. ${ }^{138}$ Together, these results suggest that the relationship between visuospatial abilities and $\mathrm{T}$ levels is better described by an inverted $U$ shape curve, with a corresponding range of optimal concentrations of $\mathrm{T}$ leading to enhanced visuospatial performance. ${ }^{138}$

It should be noted that although the link between $\mathrm{T}$ and performance in spatial tasks is well established, it may depend on the interaction between $\mathrm{T}$ and the social context. By assigning participants to a high- and low-status condition, Newman et al found that individuals with high status and high $\mathrm{T}$ performed well in both tests, while individuals with low status and high $\mathrm{T}$ (a status threatening condition) had a worse performance in both tests. ${ }^{139}$

\section{Effects of androgens on economic behavior}

The effect of $\mathrm{T}$ in the context of economic behavior and decision making has been studied, mostly using the "ultimatum game" (UG). In this game, a proposer makes an offer to a responder for how to divide an endowment, and the receiver has to decide whether to accept or reject the offer. Acceptance implies the division of the sum as suggested by the proposer, whereas rejection implies that none of the participants will receive any money. In this paradigm offers less than $20 \%$ of the total sum are considered unfair and are frequently rejected by the receiver. ${ }^{140}$ Using the $\mathrm{UG}$, Burnham reported that, in men, baseline $T$ was positively correlated with the rejection of low game offers and suggested that in settings with repeated interactions, punishment may enhance the reputation of the punisher and alter the behavior of the punished. ${ }^{141}$ Likewise, Mehta and Beer also found a positive correlation between $\mathrm{T}$ and unfair offer rejection, and this effect of $\mathrm{T}$ was similar in men and women. ${ }^{125}$

To clarify the effects of $\mathrm{T}$ on fair offers, different experiments involving the administration of T have been conducted, with mixed results. An experiment by Zak et al used a gel carrying $1 \%$ of $\mathrm{T}$ and found an effect of this androgen on offer generosity, wherein the participants in the proposer condition who received $\mathrm{T}$ made offers $27 \%$ lower than those who received placebo. ${ }^{142}$ However, this difference between groups disappeared with repeated play. In contrast, Eisenegger et al studied female participants who were given a sublingual administration of $\mathrm{T}$ and reported that the $\mathrm{T}$ had no effect on rejection behavior but also, that the group given $\mathrm{T}$ presented higher offers to the receiver than did the placebo group. ${ }^{143}$ 
This study also found an interference of the participants' beliefs about the effects of $\mathrm{T}$, since lower offers in the UG were presented by individuals in the placebo condition who believed they were given T. A recent paper that analyzed the dynamics of $\mathrm{T}$ absorption after its gel administration ${ }^{144}$ has suggested that the study by Zak et al tested subjects 13 hours after the peak of T levels. Although this result reveals a mishap in the sampling time of the Zak et al study, ${ }^{142}$ it cannot fully explain the contradictory results concerning the effects of $\mathrm{T}$ on fair bargaining, since the experimental subjects in the target experiment still presented free $\mathrm{T}$ levels that were 97\% higher than their baseline measure.

The Eisenegger et al experiment ${ }^{143}$ hinted at a prosocial dimension of $\mathrm{T}$, ie, that $\mathrm{T}$ could enable the individual to secure important resources and a high status through cooperation: supporting evidence for this was found in a recent study that used the "public goods game" as an experimental task. ${ }^{145}$ Using this economic game, the authors removed the possibility that the fair behavior found in the UG could be due to the threat of financial punishment; the researchers showed that the effect of $\mathrm{T}$ on cooperation was moderated by the 2D:4D ratio since only participants with a high $2 \mathrm{D}: 4 \mathrm{D}$ ratio (hypothetically with low fetal androgen exposure) contributed more monetary units after receiving exogenous $\mathrm{T}^{145}$

As mentioned in a previous section, it has previously been shown that $\mathrm{T}$ administration elicited increased risk taking and that this was associated with changes in punishment and reward sensitivity. ${ }^{111}$ Risk-taking has also been positively correlated with endogenous salivary $\mathrm{T}$ levels, in men playing an investment game, ${ }^{146}$ and risk-aversion has been negatively correlated with T levels, in women. ${ }^{147,148}$ Recently, a study with a mixed-sex sample also found a nonlinear U-shaped association of endogenous $\mathrm{T}$ with risk taking and with ambiguity preference in economic decision-making. ${ }^{149}$ In this experiment, a similar pattern of response was found for men and women - individuals presenting low and high $\mathrm{T}$ (ie, below and above 1.5 standard deviations from their sex mean, respectively) were neutral to risk and ambiguity, whereas risk and ambiguity aversion were found in those with midlevels of endogenous T. ${ }^{149}$

\section{The dual-hormone hypothesis of neuroendocrine response to social challenges}

Besides the role of psychological variables in the androgen response to social challenges, there is growing evidence that both dominance behavior and $\mathrm{T}$ levels change after a contest and that both are also moderated by baseline levels of $\mathrm{C}$ and $\mathrm{T}$ (reflecting an endocrine interaction between the hypothalamic-pituitary-gonadal and the hypothalamic-pituitary-adrenal axis). ${ }^{150}$ For example, basal T levels have been shown to predict the $\mathrm{C}$ response to winning or losing a competition; ${ }^{54}$ positive correlations between $\mathrm{T}$ and overt aggression have only been found when $\mathrm{C}$ levels are low; ${ }^{151}$ and a $\mathrm{T} / \mathrm{C}$ ratio has been proposed as a marker for the propensity for aggressive behavior. ${ }^{152}$ This set of results led to the recent proposal of a dual-hormone hypothesis for the regulation of dominance. ${ }^{153}$ The proposers of this hypothesis found evidence that the association between $\mathrm{T}$ and dominance was moderated by basal $\mathrm{C}$ levels in both sexes, with higher $\mathrm{T}$ predicting higher dominance scores only when baseline $\mathrm{C}$ levels were low; they found too, that high dominance after losing a competition was predicted by high precompetition $\mathrm{T}$ and low precompetition $\mathrm{C}$, a relationship that was reversed when individuals showed high $\mathrm{C}$ levels before the competition. ${ }^{153}$ This hypothesis received further support in a recent study that found the same pattern of response in the winners of a video game contest; in this study, an increased postcompetition $\mathrm{T}$ was found when the winning participants presented a high baseline $\mathrm{T}$ and low baseline $\mathrm{C} .{ }^{73}$ Together, these results support the idea that the promotion of status-seeking behaviors by high $\mathrm{T}$ only occurs when $\mathrm{C}$ levels are low. It should be noted here that the dual-hormone hypothesis establishes the interaction between $\mathrm{T}$ and $\mathrm{C}$ based on acute responses to social challenges, and this mutual regulatory pattern may not account for the changes in hormone levels occurring under chronic events. ${ }^{154}$

\section{Concluding remarks}

The androgen response to social competition is present in a wide range of animals, including humans. Overall, the literature reviewed in this article suggests that the $\mathrm{T}$ response to competition in humans displays a high degree of variability and violates the patterns of response predicted either by the biosocial model or by the challenge hypothesis. This large scope of variation in androgen responsiveness can be explained by the interaction between androgens and another neuromodulator of the social decision-making network in the brain, namely $\mathrm{C}$ (as proposed by the dual-hormone hypothesis), and by psychological variables. The possible interference of the $\mathrm{T}$ response elicited by competition by cognitive variables was first hypothesized in the biosocial model, and therefore, the biosocial model is the theoretical framework that is usually evoked when trying to understand the modulatory effects of cognition on T levels. Nevertheless, it is interesting to note that the recent revision of the challenge 
hypothesis, partly motivated by the differences in the direction of T response to territorial intrusions, also contemplates an interaction between $\mathrm{T}$ and intraindividual processes (eg, cognitive variables). ${ }^{17,18,155}$ Experimental testing of these assumptions should be addressed in future studies. Focusing on the relative contributions of these psychological and physiological moderators and on the interactions between them, should provide new perspectives on current contradictory results.

\section{Acknowledgments}

GO is supported by a $\mathrm{PhD}$ fellowship (SFRH/BD/68528/2010) from Fundação para a Ciência e a Tecnologia (FCT), Portugal. The writing of this review was supported by an FCT strategic grant to RO (PEst-OE/MAR/UI0331/2011).

\section{Disclosure}

The authors report no conflicts of interest in this work.

\section{References}

1. Adkins-Regan E. Hormonal organization and activation: evolutionary implications and questions. Gen Comp Endocrinol. 2012;176(3): 279-285.

2. Laue L, Cutler GB Jr. The adrenal cortex. In: Bittar EE, Bittar N, editors. Principles of Medical Biology: Molecular and Cellular Endocrinology. Greenwich, CT: JAI Press; 1997:227-254.

3. Longcope C. Adrenal and gonadal androgen secretion in normal females. Clin Endocrinol Metab. 1986;15(2):213-228.

4. Burger HG. Androgen production in women. Fertil Steril. 2002; 77 Suppl 4:S3-S5.

5. Schmidt KL, Pradhan DS, Shah AH, Charlier TD, Chin EH, Soma KK. Neurosteroids, immunosteroids, and the Balkanization of endocrinology. Gen Comp Endocrinol. 2008;157(3):266-274.

6. Reddy DS. Neurosteroids: endogenous role in the human brain and therapeutic potentials. Prog Brain Res. 2010;186:113-137.

7. Girdler SS, Klatzkin R. Neurosteroids in the context of stress: implications for depressive disorders. Pharmacol Ther. 2007;116(1):125-139.

8. Oliveira RF. Social modulation of androgens in vertebrates: mechanisms and function. Adv Stud Behav. 2004;34:165-239.

9. Mazur A. A biosocial model of status in face-to-face primate groups. Social Forces. 1985;64(2):377-402.

10. Mazur A, Booth A. Testosterone and dominance in men. Behav Brain Sci. 1998;21(3):353-363; discussion 363-397.

11. Eisenegger C, Haushofer J, Fehr E. The role of testosterone in social interaction. Trends Cogn Sci. 2011;15(6):263-271.

12. Josephs RA, Mehta PH, Carré JM. Gender and social environment modulate the effects of testosterone on social behavior: comment on Eisenegger et al. Trends Cogn Sci. 2011;15(11):509-510; author reply 510.

13. Wingfield JC, Hegner RE, Dufty AM Jr, Ball GF. The "Challenge Hypothesis": theoretical implications for patterns of testosterone secretion, mating systems, and breeding strategies. Am Nat. 1990;136(6): 829-846.

14. Archer J. Testosterone and human aggression: an evaluation of the challenge hypothesis. Neurosci Biobehav Rev. 2006;30(3):319-345.

15. Hirschenhauser K, Oliveira RF. Social modulation of androgens in male vertebrates: meta-analyses of the challenge hypothesis. Anim Behav. 2006;71(2):265-277.

16. Scott MP. Resource defense and juvenile hormone: the "challenge hypothesis" extended to insects. Horm Behav. 2006;49(3):276-281.
17. Goymann W, Landys MM, Wingfield JC. Distinguishing seasonal androgen responses from male-male androgen responsiveness-revisiting the Challenge Hypothesis. Horm Behav. 2007;51(4):463-476.

18. Goymann W. Social modulation of androgens in male birds. Gen Comp Endocrinol. 2009;163(1-2):149-157.

19. Wingfield JC, Lynn S, Soma KK. Avoiding the 'costs' of testosterone: ecological bases of hormone-behavior interactions. Brain Behav Evol. 2001;57(5):239-251.

20. Hau M. Regulation of male traits by testosterone: implications for the evolution of vertebrate life histories. Bioessays. 2007;29(2):133-144.

21. Schroderus E, Jokinen I, Koivula M, et al. Intra- and intersexual trade-offs between testosterone and immune system: Implications for sexual and sexually antagonistic selection. Am Nat. 2010;176(4): E90-E97.

22. Hsu Y, Earley RL, Wolf LL. Modulation of aggressive behaviour by fighting experience: mechanisms and contest outcomes. Biol Rev Camb Philos Soc. 2006;81(1):33-74.

23. Oyegbile TO, Marler CA. Winning fights elevates testosterone levels in California mice and enhances future ability to win fights. Horm Behav. 2005;48(3):259-267.

24. Fuxjager MJ, Marler CA. How and why the winner effect forms: influences of contest environment and species differences. Behav Ecol. 2009;21(1):37-45

25. Gleason ED, Fuxjager MJ, Oyegbile TO, Marler CA. Testosterone release and social context: when it occurs and why. Front Neuroendocrinol. 2009;30(4):460-469.

26. Oliveira RF. Social behavior in context: Hormonal modulation of behavioral plasticity and social competence. Integr Comp Biol. 2009;49(4): 423-440.

27. Trainor BC, Bird IM, Marler CA. Opposing hormonal mechanisms of aggression revealed through short-lived testosterone manipulations and multiple winning experiences. Horm Behav. 2004;45(2):115-121.

28. Mazur A, Lamb TA. Testosterone, status, and mood in human males. Horm Behav. 1980;14(3):236-246.

29. Elias M. Serum cortisol, testosterone, and testosterone-binding globulin responses to competitive fighting in human males. Aggress Behav. 1981;7(3):215-224.

30. Booth A, Shelley G, Mazur A, Tharp G, Kittok R. Testosterone, and winning and losing in human competition. Horm Behav. 1989;23(4):556-571.

31. Gladue BA, Boechler M, McCaul KD. Hormonal response to competition in human males. Aggress Behav. 1989;15(6):409-422.

32. Mazur A, Booth A, Dabbs JM Jr. Testosterone and chess competition. Soc Psychol Q. 1992;55(1):70-77.

33. McCaul KD, Gladue BA, Joppa M. Winning, losing, mood, and testosterone. Horm Behav. 1992;26(4):486-504.

34. Mazur A, Susman EJ, Edelbrock S. Sex difference in testosterone response to a video game contest. Evol Hum Behav. 1997;18(5):317-326.

35. Bernhardt PC, Dabbs JM, Fielden JA, Lutter CD. Testosterone changes during vicarious experiences of winning and losing among fans at sporting events. Physiol Behav. 1998;65(1):59-62.

36. Gonzalez-Bono E, Salvador A, Serrano MA, Ricarte J. Testosterone, cortisol, and mood in a sports team competition. Horm Behav. 1999; 35(1):55-62.

37. Schultheiss OC, Campbell KL, McClelland DC. Implicit power motivation moderates men's testosterone responses to imagined and real dominance success. Horm Behav. 1999;36(3):234-241.

38. Suay F, Salvador A, González-Bono E, et al. Effects of competition and its outcome on serum testosterone, cortisol and prolactin. Psychoneuroendocrinology. 1999;24(5):551-566.

39. González-Bono E, Salvador A, Ricarte J, Serrano MA, Arnedo M. Testosterone and attribution of successful competition. Aggress Behav. 2000;26(3):235-240.

40. Serrano MA, Salvador A, González-Bono E, Sanchís C, Suay F. Hormonal responses to competition. Psicothema. 2000;12(3):440-444.

41. Filaire E, Maso F, Sagnol M, Ferrand C, Lac G. Anxiety, hormonal responses, and coping during a judo competition. Aggress Behav. 2001;27(1):55-63. 
42. Bateup HS, Booth A, Shirtcliff EA, Granger DA. Testosterone, cortisol, and women's competition. Evol Hum Behav. 2002;23(3):181-192.

43. Schultheiss OC, Rohde W. Implicit power motivation predicts men's testosterone changes and implicit learning in a contest situation. Horm Behav. 2002;41(2):195-202.

44. Wagner JD, Flinn MV, England BG. Hormonal response to competition among male coalitions. Evol Hum Behav. 2002;23(6):437-442.

45. Kivlighan KT, Granger DA, Booth A. Gender differences in testosterone and cortisol response to competition. Psychoneuroendocrinology. 2005;30(1):58-71.

46. Schultheiss OC, Wirth MM, Torges CM, Pang JS, Villacorta MA, Welsh KM. Effects of implicit power motivation on men's and women's implicit learning and testosterone changes after social victory or defeat. J Pers Soc Psychol. 2005;88(1):174-188.

47. Edwards DA, Wetzel K, Wyner DR. Intercollegiate soccer: saliva cortisol and testosterone are elevated during competition, and testosterone is related to status and social connectedness with team mates. Physiol Behav. 2006;87(1):135-143.

48. Josephs RA, Sellers JG, Newman ML, Mehta PH. The mismatch effect: when testosterone and status are at odds. J Pers Soc Psychol. 2006;90(6):999-1013.

49. Mehta PH, Josephs RA. Testosterone change after losing predicts the decision to compete again. Horm Behav. 2006;50(5):684-692.

50. Parmigiani S, Bartolomucci A. In judo, Randori (free fight) and Kata (highly ritualized fight) differentially change plasma cortisol, testosterone, and interleukin levels in male participants. Aggress Behav. 2006;32(5):481-489.

51. Stanton SJ, Schultheiss OC. Basal and dynamic relationships between implicit power motivation and estradiol in women. Horm Behav. 2007;52(5):571-580.

52. van Anders SM, Watson NV. Effects of ability- and chance-determined competition outcome on testosterone. Physiol Behav. 2007;90(4): 634-642.

53. Carré JM, McCormick CM. Aggressive behavior and change in salivary testosterone concentrations predict willingness to engage in a competitive task. Horm Behav. 2008;54(3):403-409.

54. Mehta PH, Jones AC, Josephs RA. The social endocrinology of dominance: basal testosterone predicts cortisol changes and behavior following victory and defeat. J Pers Soc Psychol. 2008;94(6): 1078-1093.

55. Carré JM. No place like home: testosterone responses to victory depend on game location. Am J Hum Biol. 2009;21(3):392-394.

56. Carré JM, Putnam SK, McCormick CM. Testosterone responses to competition predict future aggressive behaviour at a cost to reward in men. Psychoneuroendocrinology. 2009;34(4):561-570.

57. Edwards DA, O'Neal JL. Oral contraceptives decrease saliva testosterone but do not affect the rise in testosterone associated with athletic competition. Horm Behav. 2009;56(2):195-198.

58. Hamilton LD, van Anders SM, Cox DN, Watson NV. The effect of competition on salivary testosterone in elite female athletes. Int J Sports Physiol Perform. 2009;4(4):538-542.

59. Mehta PH, Wuehrmann EV, Josephs RA. When are low testosterone levels advantageous? The moderating role of individual versus intergroup competition. Horm Behav. 2009;56(1):158-162.

60. Oliveira T, Gouveia MJ, Oliveira RF. Testosterone responsiveness to winning and losing experiences in female soccer players. Psychoneuroendocrinology. 2009;34(7):1056-1064.

61. Pound N, Penton-Voak IS, Surridge AK. Testosterone responses to competition in men are related to facial masculinity. Proc Biol Sci. 2009;276(1654):153-159.

62. Stanton SJ, Beehner JC, Saini EK, Kuhn CM, Labar KS. Dominance, politics, and physiology: voters' testosterone changes on the night of the 2008 United States presidential election. PLoS One. 2009;4(10):e7543.

63. Carré JM, Gilchrist JD, Morrissey MD, McCormick CM. Motivational and situational factors and the relationship between testosterone dynamics and human aggression during competition. Biol Psychol. 2010;84(2): 346-353.
64. Edwards DA, Kurlander LS. Women's intercollegiate volleyball and tennis: effects of warm-up, competition, and practice on saliva levels of cortisol and testosterone. Horm Behav. 2010;58(4):606-613.

65. Oxford J, Ponzi D, Geary DC. Hormonal responses differ when playing violent video games against an ingroup and outgroup. Evol Hum Behav. 2010;31(3):201-209.

66. Steiner ET, Barchard KA, Meana M, Hadi F, Gray PB. The deal on testosterone responses to poker competition. Curr Psychol. 2010;29(1):45-51.

67. van der Meij L, Buunk AP, Almela M, Salvador A. Testosterone responses to competition: The opponent's psychological state makes it challenging. Biol Psychol. 2010;84(2):330-335.

68. Slatcher RB, Mehta PH, Josephs RA. Testosterone and self-reported dominance interact to influence human mating behavior. Soc Psychol Personal Sci. 2011;2(5):531-539.

69. Costa R, Salvador A. Associations between success and failure in a face-to-face competition and psychobiological parameters in young women. Psychoneuroendocrinology. 2012;37(11):1780-1790.

70. Jiménez M, Aguilar R, Alvero-Cruz JR. Effects of victory and defeat on testosterone and cortisol response to competition: evidence for same response patterns in men and women. Psychoneuroendocrinology. 2012;37(9):1577-1581.

71. Trumble BC, Cummings D, von Rueden C, et al. Physical competition increases testosterone among Amazonian forager-horticulturalists: a test of the 'challenge hypothesis'. Proc Biol Sci. 2012;279(1739): $2907-2912$

72. van der Meij L, Almela M, Hidalgo V, et al. Testosterone and cortisol release among Spanish soccer fans watching the 2010 World Cup final. PLoS One. 2012;7(4):e34814

73. Zilioli S, Watson NV. The hidden dimensions of the competition effect: basal cortisol and basal testosterone jointly predict changes in salivary testosterone after social victory in men. Psychoneuroendocrinology. 2012;37(11):1855-1865.

74. Carré JM, Campbell JA, Lozoya E, Goetz SM, Welker KM. Changes in testosterone mediate the effect of winning on subsequent aggressive behaviour. Psychoneuroendocrinology. 2013;38(10):2034-2041.

75. Denson TF, Mehta PH, Ho Tan D. Endogenous testosterone and cortisol jointly influence reactive aggression in women. Psychoneuroendocrinology. 2013;38(3):416-424.

76. Oliveira GA, Uceda S, Oliveira T, Fernandes A, Garcia-Marques T, Oliveira RF. Threat perception and familiarity moderate the androgen response to competition in women. Front Psychol. 2013;4:389.

77. Dabbs JM, de La Rue D. Salivary testosterone measurements among women: relative magnitude of circadian and menstrual cycles. Horm Res. 1991;35(5):182-184.

78. Liening SH, Stanton SJ, Saini EK, Schultheiss OC. Salivary testosterone, cortisol, and progesterone: two-week stability, interhormone correlations, and effects of time of day, menstrual cycle, and oral contraceptive use on steroid hormone levels. Physiol Behav. 2010;99(1):8-16.

79. Salvador A. Coping with competitive situations in humans. Neurosci Biobehav Rev. 2005;29(1):195-205.

80. Salvador A, Costa R. Coping with competition: neuroendocrine responses and cognitive variables. Neurosci Biobehav Rev. 2009;33(2): $160-170$.

81. Kemper TD. Fantasy, females, sexuality, and testosterone. Behav Brain Sci. 1998;21(03):378-379.

82. van Anders SM, Watson NV. Social neuroendocrinology: Effects of social contexts and behaviors on sex steroids in humans. Hum Nat. 2006; 17(2):212-237

83. Grant VJ, France JT. Dominance and testosterone in women. Biol Psychol. 2001;58(1):41-47.

84. Cashdan E. Hormones and competitive aggression in women. Aggress Behav. 2003;29:107-115.

85. Wirth MM, Schultheiss OC. Basal testosterone moderates responses to anger faces in humans. Physiol Behav. 2007;90(2-3):496-505.

86. Edwards DA. Competition and testosterone. Horm Behav. 2006;50: 681-683. 
87. Klinesmith J, Kasser T, McAndrew FT. Guns, testosterone, and aggression: an experimental test of a mediational hypothesis. Psychol Sci. 2006;17(7):568-571.

88. Mendl M, Burman OH, Paul ES. An integrative and functional framework for the study of animal emotion and mood. Proc Biol Sci. 2010;277(1696):2895-2904.

89. Lazarus RS. Cognition and motivation in emotion. Am Psychol. 1991;46(4):352-367.

90. Scherer KR. Appraisal considered as a process of multilevel sequential checking. In: Scherer KR, Schorr A, Johnstone T, editors. Appraisal Processes in Emotion: Theory, Methods, Research. New York, NY Oxford University Press; 2001:92-120.

91. Oliveira RF, Carneiro LA, Canário AV. Behavioural endocrinology: no hormonal response in tied fights. Nature. 2005;437(7056):207-208.

92. Hirschenhauser K, Taborsky M, Oliveira T, Canario AVM, Oliveira RF A test of the 'challenge hypothesis' in cichlid fish: simulated partner and territory intruder experiments. Anim Behav. 2004;68(4): 741-750.

93. Hirschenhauser K, Wittek M, Johnston P, Möstl E. Social context rather than behavioral output or winning modulates post-conflict testosterone responses in Japanese quail (Coturnix japonica). Physiol Behav. 2008;95(3):457-463.

94. Neave N, Wolfson S. Testosterone, territoriality, and the 'home advantage'. Physiol Behav. 2003;78(2):269-275.

95. Carré J, Muir C, Belanger J, Putnam SK. Pre-competition hormonal and psychological levels of elite hockey players: relationship to the "home advantage". Physiol Behav. 2006;89(3):392-398.

96. Stanton SJ, Schultheiss OC. The hormonal correlates of implicit power motivation. J Res Pers. 2009;43(5):942.

97. Hartgens F, Kuipers H. Effects of androgenic-anabolic steroids in athletes. Sports Med. 2004;34(8):513-554.

98. Husak JF, Irschick DJ. Steroid use and human performance: Lessons for integrative biologists. Integr Comp Biol. 2009;49(4):354-364.

99. Wood RI, Stanton SJ. Testosterone and sport: current perspectives. Horm Behav. 2012;61(1):147-155.

100. Bhasin S, Woodhouse L, Storer TW. Proof of the effect of testosterone on skeletal muscle. J Endocrinol. 2001;170(1):27-38.

101. Adkins-Regan E. Hormones and Animal Social Behavior. Princeton, NJ: Princeton University Press; 2005

102. Bradley BP, Mogg K, Falla SJ, Hamilton LR. Attentional bias for threatening facial expressions in anxiety: manipulation of stimulus duration. Cogn Emot. 1998;12(6):737-753.

103. Bradley BP, Mogg K, Millar NH. Covert and overt orienting of attention to emotional faces in anxiety. Cogn Emotion. 2000;14(6):789-808.

104. Frye CA, Seliga AM. Testosterone increases analgesia, anxiolysis, and cognitive performance of male rats. Cogn Affect Behav Neurosci. 2001;1(4):371-381

105. Aikey JL, Nyby JG, Anmuth DM, James PJ. Testosterone rapidly reduces anxiety in male house mice (Mus musculus). Horm Behav 2002;42(4):448-460.

106. van Honk J, Peper JS, Schutter DJ. Testosterone reduces unconscious fear but not consciously experienced anxiety: implications for the disorders of fear and anxiety. Biol Psychiatry. 2005;58(3): $218-225$.

107. Hermans EJ, Putman P, Baas JM, Koppeschaar HP, van Honk J. A single administration of testosterone reduces fear-potentiated startle in humans. Biol Psychiatry. 2006;59(9):872-874.

108. Hermans EJ, Putman P, Baas JM, Gecks NM, Kenemans JL, van Honk J. Exogenous testosterone attenuates the integrated central stress response in healthy young women. Psychoneuroendocrinology. 2007;32(8-10):1052-1061.

109. van Honk J, Schutter DJ. Testosterone reduces conscious detection of signals serving social correction: implications for antisocial behavior. Psychol Sci. 2007;18(8):663-667.

110. van Honk J, Tuiten A, Hermans E, et al. A single administration of testosterone induces cardiac accelerative responses to angry faces in healthy young women. Behav Neurosci. 2001;115(1):238-242.
111. van Honk J, Schutter DJ, Hermans EJ, Putman P, Tuiten A, Koppeschaar H. Testosterone shifts the balance between sensitivity for punishment and reward in healthy young women. Psychoneuroendocrinology. 2004;29(7):937-943.

112. van Honk J, Tuiten A, Verbaten R, et al. Correlations among salivary testosterone, mood, and selective attention to threat in humans. Horm Behav. 1999;36(1):17-24.

113. van Honk J, Tuiten A, van den Hout M, et al. Conscious and preconscious selective attention to social threat: different neuroendocrine response patterns. Psychoneuroendocrinology. 2000;25(6):577-591.

114. Bos PA, Terburg D, van Honk J. Testosterone decreases trust in socially naive humans. Proc Natl Acad Sci U S A. 2010;107(22):9991-9995.

115. Hermans EJ, Putman P, van Honk J. Testosterone administration reduces empathetic behavior: a facial mimicry study. Psychoneuroendocrinology. 2006;31(7):859-866.

116. van Honk J, Schutter DJ, Bos PA, Kruijt AW, Lentjes EG, Baron-Cohen S. Testosterone administration impairs cognitive empathy in women depending on second-to-fourth digit ratio. Proc Natl Acad Sci U S A. 2011;108(8):3448-3452.

117. Berenbaum SA, Bryk KK, Nowak N, Quigley CA, Moffat S. Fingers as a marker of prenatal androgen exposure. Endocrinology. 2009;150(11):5119-5124.

118. Hermans EJ, Ramsey NF, van Honk J. Exogenous testosterone enhances responsiveness to social threat in the neural circuitry of social aggression in humans. Biol Psychiatry. 2008;63(3): 263-270.

119. van Wingen GA, Zylicz SA, Pieters S, et al. Testosterone increases amygdala reactivity in middle-aged women to a young adulthood level. Neuropsychopharmacology. 2009;34(3):539-547.

120. Derntl B, Windischberger C, Robinson S, et al. Amygdala activity to fear and anger in healthy young males is associated with testosterone. Psychoneuroendocrinology. 2009;34(5):687-693.

121. Manuck SB, Marsland AL, Flory JD, Gorka A, Ferrell RE, Hariri AR Salivary testosterone and a trinucleotide (CAG) length polymorphism in the androgen receptor gene predict amygdala reactivity in men. Psychoneuroendocrinology. 2010;35(1):94-104.

122. Ochsner KN, Gross JJ. The cognitive control of emotion. Trends Cogn Sci. 2005;9(5):242-249.

123. Coccaro EF, McCloskey MS, Fitzgerald DA, Phan KL. Amygdala and orbitofrontal reactivity to social threat in individuals with impulsive aggression. Biol Psychiatry. 2007;62(2):168-178.

124. van Wingen G, Mattern C, Verkes RJ, Buitelaar J, Fernández G. Testosterone reduces amygdala-orbitofrontal cortex coupling. Psychoneuroendocrinology. 2010;35(1):105-113.

125. Mehta PH, Beer J. Neural mechanisms of the testosteroneaggression relation: the role of orbitofrontal cortex. J Cogn Neurosci. 2010;22(10):2357-2368

126. Hermans EJ, Bos PA, Ossewaarde L, Ramsey NF, Fernández G, van Honk J. Effects of exogenous testosterone on the ventral striatal BOLD response during reward anticipation in healthy women. Neuroimage. 2010;52(1):277-283.

127. Liben LS, Susman EJ, Finkelstein JW, et al. The effects of sex steroids on spatial performance: a review and an experimental clinical investigation. Dev Psychol. 2002;38(2):236-253.

128. Silverman I, Kastuk D, Choi J, Phillips K. Testosterone levels and spatial ability in men. Psychoneuroendocrinology. 1999;24(8):813-822.

129. Thilers PP, Macdonald SW, Herlitz A. The association between endogenous free testosterone and cognitive performance: a population-based study in 35 to 90 year-old men and women. Psychoneuroendocrinology. 2006;31(5):565-576.

130. Van Strien JW, Weber RF, Burdorf A, Bangma C. Higher free testosterone level is associated with faster visual processing and more flanker interference in older men. Psychoneuroendocrinology. 2009;34(4):546-554

131. Moffat SD, Hampson E. A curvilinear relationship between testosterone and spatial cognition in humans: possible influence of hand preference. Psychoneuroendocrinology. 1996;21(3):323-337. 
132. Yonker JE, Eriksson E, Nilsson LG, Herlitz A. Negative association of testosterone on spatial visualization in 35 to 80 year old men. Cortex. 2006;42(3):376-386.

133. Matousek RH, Sherwin BB. Sex steroid hormones and cognitive functioning in healthy, older men. Horm Behav. 2010;57(3):352-359.

134. Postma A, Meyer G, Tuiten A, van Honk J, Kessels RP, Thijssen J. Effects of testosterone administration on selective aspects of objectlocation memory in healthy young women. Psychoneuroendocrinology. 2000;25(6):563-575.

135. Aleman A, Bronk E, Kessels RP, Koppeschaar HP, van Honk J. A single administration of testosterone improves visuospatial ability in young women. Psychoneuroendocrinology. 2004;29(5):612-617.

136. Janowsky JS, Oviatt SK, Orwoll ES. Testosterone influences spatial cognition in older men. Behav Neurosci. 1994;108(2):325-332.

137. Cherrier MM, Asthana S, Plymate S, et al. Testosterone supplementation improves spatial and verbal memory in healthy older men. Neurology. 2001;57(1):80-88.

138. O'Connor DB, Archer J, Hair WM, Wu FC. Activational effects of testosterone on cognitive function in men. Neuropsychologia. 2001; 39(13):1385-1394.

139. Newman ML, Sellers JG, Josephs RA. Testosterone, cognition, and social status. Horm Behav. 2005;47(2):205-211.

140. Camerer CF. Progress in behavioral game theory. J Econ Perspect. 1997;11(4):167-188.

141. Burnham TC. High-testosterone men reject low ultimatum game offers. Proc Biol Sci. 2007;274(1623):2327-2330.

142. Zak PJ, Kurzban R, Ahmadi S, et al. Testosterone administration decreases generosity in the ultimatum game. PLoS One. 2009;4(12): e8330.

143. Eisenegger C, Naef M, Snozzi R, Heinrichs M, Fehr E. Prejudice and truth about the effect of testosterone on human bargaining behaviour. Nature. 2010;463(7279):356-359.

144. Eisenegger C, von Eckardstein A, Fehr E, von Eckardstein S. Pharmacokinetics of testosterone and estradiol gel preparations in healthy young men. Psychoneuroendocrinology. 2013;38(2): $171-178$.
145. van Honk J, Montoya ER, Bos PA, van Vugt M, Terburg D. New evidence on testosterone and cooperation. Nature. 2012;485(7399): E4-E5; discussion E5-E6.

146. Apicella CL, Dreber A, Campbell B, Gray PB, Hoffman M, Little AC. Testosterone and financial risk preferences. Evol Hum Behav. 2008;29(6):384-390.

147. Sapienza P, Zingales L, Maestripieri D. Gender differences in financial risk aversion and career choices are affected by testosterone. Proc Natl Acad Sci U S A. 2009;106(36):15268-15273.

148. Joel D, Tarrasch R. The risk of a wrong conclusion: on testosterone and gender differences in risk aversion and career choices. Proc Natl Acad Sci U S A. 2010;107(5):E19; author reply E20.

149. Stanton SJ, Mullette-Gillman OA, McLaurin RE, et al. Low- and high-testosterone individuals exhibit decreased aversion to economic risk. Psychol Sci. 2011;22(4):447-453.

150. Viau V. Functional cross-talk between the hypothalamic-pituitarygonadal and -adrenal axes. J Neuroendocrinol. 2002;14(6):506-513.

151. Popma A, Vermeiren R, Geluk CA, et al. Cortisol moderates the relationship between testosterone and aggression in delinquent male adolescents. Biol Psychiatry. 2007;61(3):405-411.

152. Terburg D, Morgan B, van Honk J. The testosterone-cortisol ratio: A hormonal marker for proneness to social aggression. Int $J$ Law Psychiatry. 2009;32(4):216-223.

153. Mehta PH, Josephs RA. Testosterone and cortisol jointly regulate dominance: evidence for a dual-hormone hypothesis. Horm Behav. 2010;58(5):898-906.

154. Gettler LT, McDade TW, Kuzawa CW. Cortisol and testosterone in Filipino young adult men: evidence for co-regulation of both hormones by fatherhood and relationship status. Am J Hum Biol. 2011;23(5):609-620.

155. Kempenaers B, Peters A, Foerster K. Sources of individual variation in plasma testosterone levels. Philos Trans R Soc Lond B Biol Sci. 2008;363(1497):1711-1723.
Neuroscience and Neuroeconomics

\section{Publish your work in this journal}

Neuroscience and Neuroeconomics is an international, peer-reviewed, open access journal focusing on the identification of brain structures and measurement of neural activity related to behavior, behavioral predictions, and decision making in health and disease. The manuscript management system is completely online and includes a very quick and

\section{Dovepress}

fair peer-review system. Visit http://www.dovepress.com/testimonials. php to read real quotes from published authors. 